\title{
OCULAR MANIFESTATION IN HIV- A CLINICAL STUDY AT TERTIARY CENTRE
}

\author{
Chelluboyina Manga Venkat ${ }^{1}$, Chodipelli Guru Murthy²
}

${ }^{1}$ Civil Assistant Surgeon, Department of Ophthalmology, Government Regional Eye Hospital, Andhra Medical College, Visakhapatnam, Andhra Pradesh.

${ }^{2}$ Assistant Professor, Department of Ophthalmology, GEMS, Srikakulam, Andhra Pradesh.

\begin{tabular}{l}
\hline ABSTRACT \\
\hline BACKGROUND \\
The human immunodeficiency virus (HIV) infection has spread worldwide with various adverse health and economic implications, \\
particularly in the developing world.(1) Ocular involvement in AIDS is very common and includes various clinical \\
presentations. $(2,3,4,5,6,7,8,9)$ \\
The aim of this study is to study various ocular manifestations in the cases known to be infected with HIV (Human \\
Immunodeficiency Virus).
\end{tabular}

\section{MATERIALS AND METHODS}

Prospective clinical study from October 2010 to November 2012 at Govt. Regional Eye Hospital, Visakhapatnam, in association with Antiretroviral treatment (ART) Centre, KGH, Visakhapatnam.

\section{RESULTS}

Out of 960 HIV positive patients examined, 201 (20.93\%) patients had ocular manifestations. Of these 201 patients, adults were $192(95.5 \%)$ and children were $9(4.5 \%)$. Out of these 201 patients age group 0 - 20 were 16 (7.96\%), age group 20 - 40 were 120 (59.7\%), age group $40-60$ were 55 (27.36\%), age group > 60 were 10 (4.97\%). 126 cases (62.7\%) had anterior segment manifestations and $75(37.3 \%)$ had posterior segment manifestations. Anterior segment manifestations include dry eye (12.43\%), blepharitis (7.46\%), molluscum (4.97\%), OSSN (0.99\%), dendritic ulcer (4.47\%), fungal ulcer (3.98\%), iridocyclitis (7.46\%), HZO (9.45\%), conjunctivitis (5.47\%), nerve palsy (0.99\%), stye $(4.47 \%)$ and chronic dacryocystitis $(0.49 \%)$. Posterior segment manifestations include HIV retinopathy (15.42\%), CMV retinitis $(12.43 \%)$, optic atrophy (1.49\%), choroiditis (4.47\%), PORN $(1.49 \%)$ and retinal detachment (1.99\%). Out of 201, $23(11.44 \%)$ had CD4 count < 50, 40 (19.9\%) had CD4 count 50 - 100, 120 (59.7\%) had CD4 count $200-500$ and $18(8.95 \%)$ had CD4 count > 500. 93 (46.3\%) were on HAART and 108 (53.7\%) were on pre-HAART.

\section{CONCLUSION}

The prevalence of ocular manifestations in HIV patients is 20.93\%, commonly involving age group between 20 - 40 yrs. of age. HIV microangiopathy was the most common ocular manifestation in HIV patients and it was the common posterior segment manifestation. Anterior segment being the commonly involved segment in HIV patients and common anterior segment manifestation was dry eye. CMV retinitis was the most common opportunistic infection in patients with HIV and it was associated with CD4 count $<50$ cells/microlitre. Patients on HAART therapy showed less manifestations compared to pre-HAART patients.

\section{KEYWORDS}

HIV, Ocular Manifestations

HOW TO CITE THIS ARTICLE: Venkat CM, Murthy CG. Ocular manifestation in HIV- a clinical study at tertiary centre. J. Evolution Med. Dent. Sci. 2018;7(11):1418-1422, DOI: 10.14260/jemds/2018/322

\section{BACKGROUND}

The human immunodeficiency virus (HIV) infection has spread worldwide with various adverse health and economic implications, particularly in the developing world.(1) Ocular involvement in AIDS is very common and includes various clinical presentations. $(2,3,4,5,6,7,8,9)$ The latest statistics of the global HIV and AIDS epidemic published by UNAIDS, WHO and UNICEF in Nov 2011 estimated that 34 million people were living with HIV/ AIDS.[10] HIV causes a wide spectrum of diseases $(2,3,4)$ including an acute mononucleosis-like syndrome, an asymptomatic carrier state, persistent generalised lymphadenopathy, AIDS-related complex and AIDS itself.

'Financial or Other Competing Interest': None.

Submission 08-02-2017, Peer Review 18-11-2017,

Acceptance 25-11-2017, Published 12-03-2018.

Corresponding Author:

Dr. Chelluboyina Manga Venkat,

Civil Assistant Surgeon, Department of Ophthalmology,

Government Regional Eye Hospital,

Andhra Medical College, Visakhapatnam.

E-mail: chmanga@ymail.com

DOI: $10.14260 /$ jemds $/ 2018 / 322$
Numerous ophthalmic manifestations of HIV infection may involve the anterior or posterior segment of the eye. Since the first report of the ocular manifestations of AIDS by Holland et al in 1982,(11,12) subsequent studies have described several AIDS related conditions in the eye and orbit. 70\% $80 \%$ of adult AIDS patients will experience an ocular complication at some point of their illness.(11,13) Orbital and adnexal findings include tumours of the periocular tissues and external infections. Anterior segment manifestations consist of keratitis, keratoconjunctivitis sicca, iridocyclitis and other complications. Posterior segment findings include a HIV associated retinopathy and a number of opportunistic infections (OI) of the retina and choroid. HIV has also been related to neuro-ophthalmic manifestations such as nerve palsies, visual field defects, papilloedema and diplopia.

\section{Inclusion Criteria}

- All patients with HIV positive status presenting to ART centre at $\mathrm{KGH}$.

- Patients presenting to Govt. REH with fundus pathologies suspected to have HIV retinopathy were taken. 


\section{MATERIALS AND METHODS}

After obtaining an informed consent from the patient satisfying the inclusion criteria, the patient was subjected to the following Examinations:

- Examination of Orbit and Ocular Adnexa with diffuse illumination.

- Slit Lamp Examination of Anterior Segment of the Eye which includes examination of Eyelids, Conjunctiva, Cornea, Anterior Chamber, Iris, Pupil and Lens.

- Instillation of Mydriatic eye drops for dilating pupil (Tropicamide eye drops) is done after examination of anterior segment, so as to visualise the posterior segment.

- Examination of Fundus is done with Direct as well as Indirect Ophthalmoscopy.

- $\quad$ Fundus pictures are documented with the help of Zeiss digital fundus camera.

- B-Scan Ultrasonography for assessment of posterior segment is done in case of media opacities where ophthalmoscopy is not possible.

- $\quad$ Blood test for CD4 count, Haemoglobin, TC, DC and ESR.

- Mantoux, chest x-ray PA view.

\section{RESULTS}

201 patients had ocular manifestations out of 960 HIV positive patients examined, which was $20.93 \%$. Of these 201 patients, adults were 192 and children were 9.

\begin{tabular}{|c|c|c|}
\hline Gender & No. of Cases & Percentage \\
\hline Male & 110 & $54.7 \%$ \\
\hline Female & 82 & $40.79 \%$ \\
\hline Children & 9 & $4.47 \%$ \\
\hline \multicolumn{2}{|c|}{ Table 1. No. of Cases according to Gender } \\
\hline
\end{tabular}

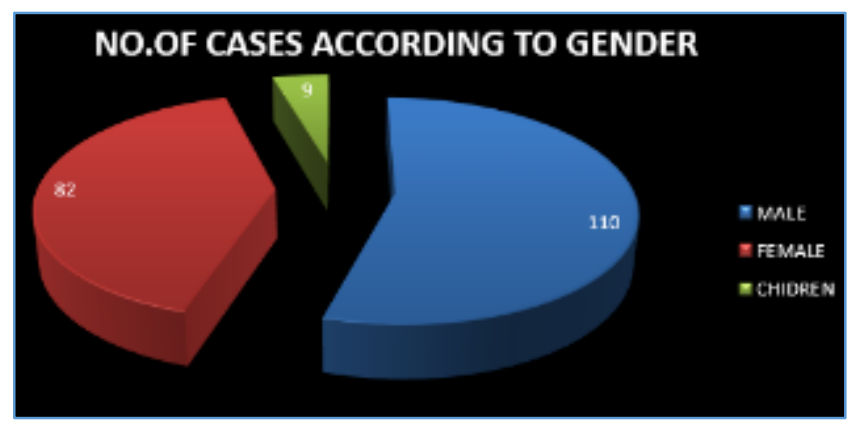

Figure 1. HIV Patients with Age

The following were the number of cases according to age group in 201 patients. Age group between $20-40$ yrs. was commonly affected.

\begin{tabular}{|c|c|c|}
\hline Age Group & No. of Patients & Percentage \\
\hline $0-20$ & 16 & $7.96 \%$ \\
\hline $20-40$ & 120 & $59.70 \%$ \\
\hline $40-60$ & 55 & $27.36 \%$ \\
\hline$>60$ & 10 & $4.97 \%$ \\
\hline \multicolumn{2}{|c|}{ Table 2. Number of Patients according to Age Group } \\
\hline
\end{tabular}

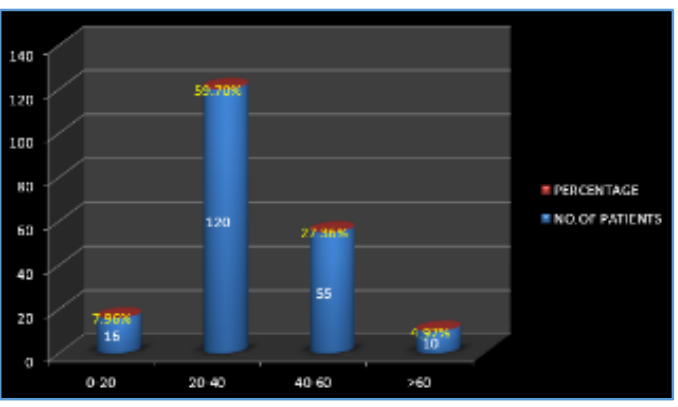

Figure 2. Age Group with HIV Patients

The following were the number of cases according to involvement of segment of the eye in 201 patients.

\begin{tabular}{|c|c|c|}
\hline Segment of the Eye & No. of Cases & Percentage \\
\hline Anterior & 126 & $62.68 \%$ \\
\hline Posterior & 75 & $37.31 \%$ \\
\hline
\end{tabular}

Table 3. No. of Cases according to Involvement of Segment

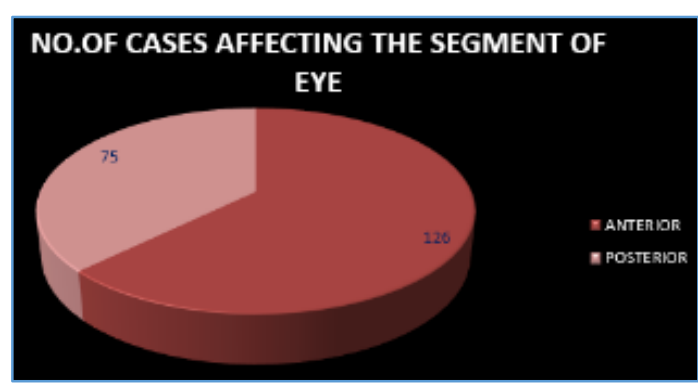

Figure 3. Anterior Segment vs Posterior Segment Involvement

The following were the various anterior segment manifestations encountered in 201 patients.

\begin{tabular}{|c|c|c|}
\hline Manifestation & No. of Cases & Percentage \\
\hline Dry eye & 25 & $12.43 \%$ \\
\hline Blepharitis & 15 & $7.46 \%$ \\
\hline Molluscum & 10 & $4.97 \%$ \\
\hline OSSN & 2 & $0.99 \%$ \\
\hline Dendritic ulcer & 9 & $4.47 \%$ \\
\hline Fungal ulcer & 8 & $3.98 \%$ \\
\hline Iridocyclitis & 15 & $7.46 \%$ \\
\hline HZO & 19 & $9.45 \%$ \\
\hline Conjunctivitis & 11 & $5.47 \%$ \\
\hline Nerve Palsy & 2 & $0.99 \%$ \\
\hline Stye & 9 & $4.47 \%$ \\
\hline Chronic dacryocystitis & 1 & $0.49 \%$ \\
\hline \multicolumn{2}{|c|}{ Table 4. Anterior Segment Manifestations } \\
\hline
\end{tabular}

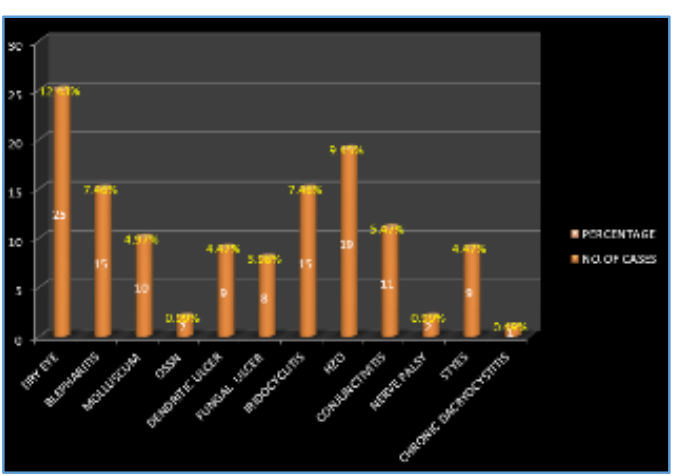

Figure 4. Shows various Anterior Segment Involvement 
The following were the various posterior segment manifestations encountered in 201 patients.

\begin{tabular}{|c|c|c|}
\hline Manifestation & No. of Cases & Percentage \\
\hline HIV Retinopathy & 31 & $15.42 \%$ \\
\hline CMV Retinitis & 25 & $12.43 \%$ \\
\hline Optic atrophy & 3 & $1.49 \%$ \\
\hline Choroiditis & 9 & $4.47 \%$ \\
\hline PORN & 3 & $1.49 \%$ \\
\hline RD & 4 & $1.99 \%$ \\
\hline Table 5. Posterior Segment Manifestations \\
\hline
\end{tabular}

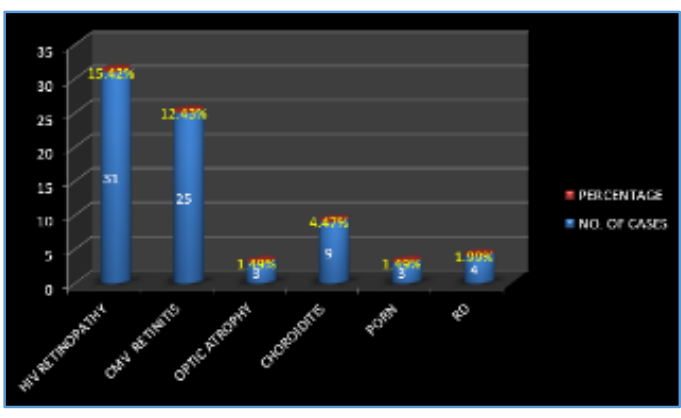

Figure 5. Shows various Posterior Segment Involvement

The following were the no. of patients in relation to CD4 count in 201 patients.

\begin{tabular}{|c|c|c|}
\hline CD4 Count & No. of Patients & Percentage \\
\hline$<50$ & 23 & $11.44 \%$ \\
\hline $50-200$ & 40 & $19.90 \%$ \\
\hline $200-500$ & 120 & $59.70 \%$ \\
\hline$>500$ & 18 & $8.95 \%$ \\
\hline Table 6. No. of Patients according to CD4 Count \\
\hline
\end{tabular}

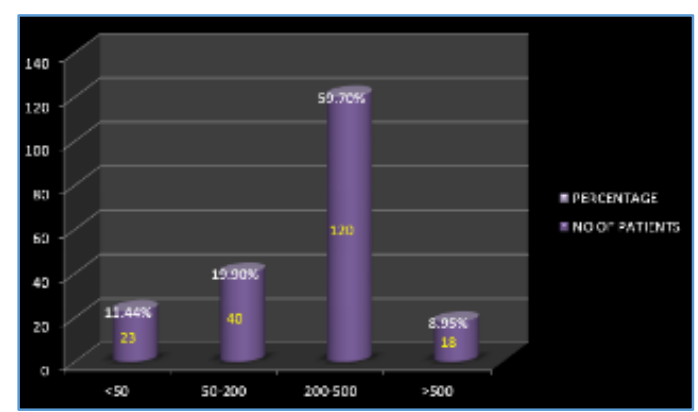

Figure 6. Shows HIV Patients and CD4 Count

\begin{tabular}{|c|c|c|}
\hline Treatment & No. of Patients & Percentage \\
\hline On HAART & 93 & $46.26 \%$ \\
\hline Pre-HAART & 108 & $53.73 \%$ \\
\hline \multicolumn{2}{|c|}{ Table 7. No. of Patients in Relation to Treatment } \\
\hline
\end{tabular}

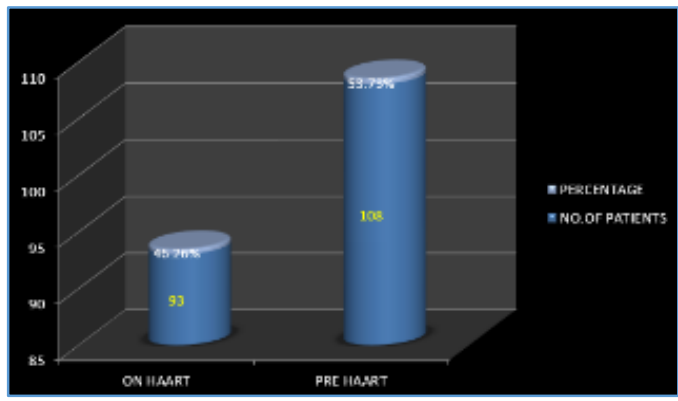

Figure 7. HIV Patient with Treatment
The following were the various common manifestations encountered in 201 patients according to CD4 count.

\begin{tabular}{|c|c|}
\hline CD4 Counts & Common Manifestation \\
\hline$<50$ & CMV Retinitis \\
\hline $50-200$ & HIV Retinopathy \\
\hline $200-500$ & Choroiditis \\
\hline$>500$ & Dry Eye \\
\hline $\begin{array}{c}\text { Table 8. Most Common Manifestations in Relation to } \\
\text { various Ranges of CD4 Count in our Study }\end{array}$ \\
\hline
\end{tabular}

\section{Retinitis - HIV Retinopathy}

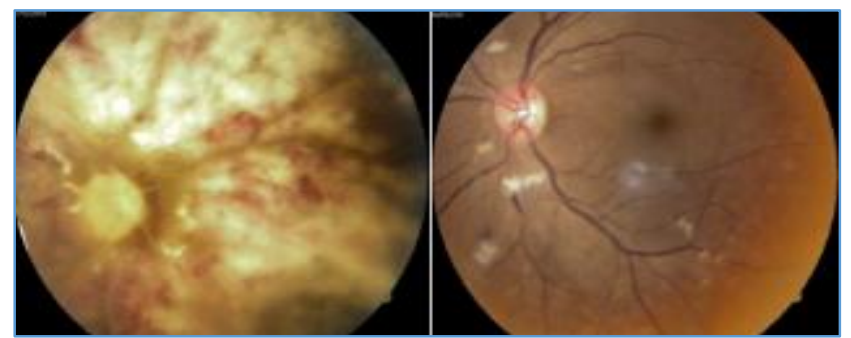

Figure 8

Figure 9

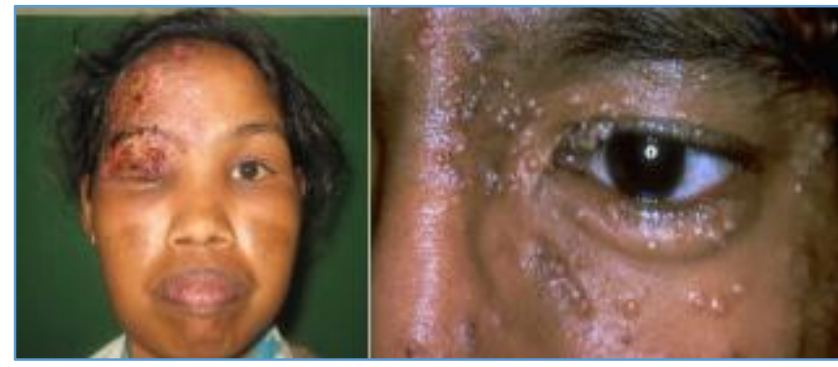

Figure 10. HZO

Figure 11. Molluscum

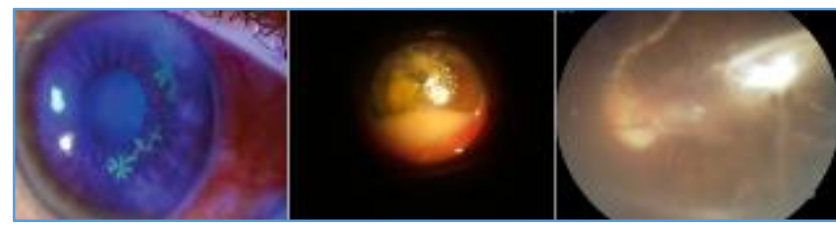

Figure 12. Dendritic Ulcer; Figure 13. Fungal Ulcer; Figure 14. Retinal Detachment

\section{DISCUSSION}

According to study done by Dr. Md. Ather, Dr. Mustafa Ahtesham and Mr. Siva Rama Krishna(14)- Incidence of ocular involvement in HIV Positive Clients/ Attending Integrated Counselling and Testing Centre- out of 595 HIV positive cases 119 (20\%) were found to be having ocular involvement, but in our study $20.93 \%$ showed ocular manifestations. Among those who were having ocular involvement, 71 (59\%) were males and 48 (41\%) were females. In our study $54.70 \%$ were males and $40.79 \%$ were females having ocular manifestations. Various manifestations are Molluscum contagiosum (4) 3.36\%, in our study 4.97\%; Herpes zoster ophthalmicus (6) $5.04 \%$, in our study 9.45\%; Orbital lymphomas (2) $1.68 \%$, in our study no orbital lymphomas were noted; OSSN (11) 9.24\%, in our study 0.99\%; Dendritic ulcer (2) $1.68 \%$, in our study $4.47 \%$; Fungal keratitis (1) $0.84 \%$, in our study $3.98 \%$; Iridocyclitis Ac/Ch (63) 52.94\%, in our study $7.46 \%$; Choroiditis (3) $2.52 \%$, in our study 4.47\%; CMV retinitis (13) $10.92 \%$, in our study $12.43 \%$; HIV retinopathy (11) $9.24 \%$, in our study $15.42 \%$; Optic atrophy 
(1) $0.84 \%$, in our study $1.49 \%$ were noted. According to this study most common ocular manifestation was iridocyclitis, in our study most common manifestation was HIV macroangiopathy.

According to the study, ocular manifestations in HIV/AIDS cases in Nepal by Lamichhane et al(15)- A total of 117 HIV infected cases were included in this study. The mean age of the subjects was $30.04+/-11.32$ years. In our study, $20-40$ years' age group were having more ocular manifestations. Ocular involvement was seen in 55 (47\%) patients; in our study ocular manifestations were seen in $20.93 \%$. The common anterior segment findings were herpes zoster ophthalmicus (4.27\%), in our study it was $9.45 \%$; anterior uveitis was (2.56\%), in our study anterior uveitis was $7.46 \%$, blepharitis was (2.56\%), in our study it was $7.46 \%$; conjunctivitis was $(1.7 \%)$, in our study it was $5.47 \%$; whereas HIV retinopathy was (19.6\%), in our study it was $15.42 \%$; CMV retinitis was (5.1\%), in our study it was $12.43 \%$; ocular toxoplasmosis was $(2.5 \%)$ and presumed ocular tuberculosis of $(0.85 \%)$ were common posterior segment findings.

Kestelyn et al(16) described the ocular manifestations of HIV/ AIDS infection in an African paediatric population. The overall rate of ophthalmic involvement was $54 \%$, in our study it was $20.93 \%$. The most common finding was a perivasculitis of the peripheral retinal vessels, observed in $38 \%$ of the patients. According to our study, it was $15.42 \%$. CMV infection of the retina was diagnosed in $10.43 \%$; in our study, it was $12.43 \%$. They concluded that cotton-wool spots and CMV retinitis are the most common ocular manifestations of HIV/ AIDS. In our study, HIV microangiopathy was the most common ocular manifestation.

In the present study, the prevalence of ocular manifestations in HIV patients is 20.93\%. HIV microangiopathy $(15.42 \%)$ was the most common ocular manifestation in HIV patients. Common anterior segment manifestation was dry eye (12.43\%) and common posterior segment manifestation was HIV microangiopathy (15.43\%). CMV retinitis (12.43\%) was most common opportunistic infection in patients with HIV. Males (54.70\%) are being more commonly affected than females (40.79\%). Anterior segment $(62.68 \%)$ being the commonly involved segment in HIV patients. Commonly involving age group is between 20 40 years (59.70\%) of age. Patients on HAART $(46.26 \%)$ therapy showing less manifestations compared to pre-HAART $(53.73 \%)$ patients. CMV retinitis was associated with CD4 count $<50$ cells/ microlitre. Various ocular manifestations are as follows: Table 9.

\begin{tabular}{|c|c|c|}
\hline Manifestation & No. of Cases & Percentage \\
\hline Dry Eye & 25 & $12.43 \%$ \\
\hline Blepharitis & 15 & $7.46 \%$ \\
\hline Molluscum & 10 & $4.97 \%$ \\
\hline OSSN & 2 & $0.99 \%$ \\
\hline Dendritic Ulcer & 9 & $4.47 \%$ \\
\hline Fungal Ulcer & 8 & $3.98 \%$ \\
\hline Iridocyclitis & 15 & $7.46 \%$ \\
\hline HZO & 19 & $9.45 \%$ \\
\hline Conjunctivitis & 11 & $5.47 \%$ \\
\hline Nerve Palsy & 2 & $0.99 \%$ \\
\hline Styes & 9 & $4.47 \%$ \\
\hline Chronic Dacryocystitis & 1 & $0.49 \%$ \\
\hline HIV Retinopathy & 31 & $15.42 \%$ \\
\hline CMV Retinitis & 25 & $12.43 \%$ \\
\hline Optic Atrophy & 3 & $1.49 \%$ \\
\hline Choroiditis & 9 & $4.47 \%$ \\
\hline PORN & 3 & $1.49 \%$ \\
\hline RD & 4 & $1.99 \%$ \\
\hline Table 9. Comparison with various Other Studies \\
\hline \multicolumn{2}{|c|}{}
\end{tabular}

\begin{tabular}{|c|c|c|c|c|c|c|c|c|}
\hline $\begin{array}{c}\text { Ocular } \\
\text { Lesion }\end{array}$ & $\begin{array}{c}\text { Awan et al, } \\
\text { Kenya(17) }\end{array}$ & $\begin{array}{c}\text { Jabs et al, } \\
\text { USA(18) }\end{array}$ & $\begin{array}{c}\text { Biswas et al, } \\
\text { India(19) }\end{array}$ & $\begin{array}{c}\text { S. K. Mandal } \\
\text { et al }\end{array}$ & $\begin{array}{c}\text { S. P. Sahoo } \\
\text { et al }\end{array}$ & $\begin{array}{c}\text { Md. Ather } \\
\text { et al(14) }\end{array}$ & $\begin{array}{c}\text { Lamichhane } \\
\text { et al(15) }\end{array}$ & $\begin{array}{c}\text { In Our } \\
\text { Study }\end{array}$ \\
\hline Molluscum & $*$ & $*$ & $*$ & $*$ & $1.5 \%$ & $3.36 \%$ & $*$ & $4.97 \%$ \\
\hline HZO & $*$ & $*$ & $*$ & $*$ & $4.54 \%$ & $5.04 \%$ & $4.27 \%$ & $9.45 \%$ \\
\hline $\begin{array}{c}\text { Orbital } \\
\text { Lymphoma }\end{array}$ & $*$ & $*$ & $*$ & $*$ & $*$ & $1.68 \%$ & $*$ & $7.46 \%$ \\
\hline OSSN & $*$ & $*$ & $*$ & $*$ & $*$ & $9.24 \%$ & $*$ & $0.99 \%$ \\
\hline Dendritic Ulcer & $*$ & $*$ & $*$ & $*$ & $*$ & $1.68 \%$ & $*$ & $4.47 \%$ \\
\hline Fungal Ulcer & $*$ & $*$ & $*$ & $*$ & $*$ & $0.84 \%$ & $*$ & $3.98 \%$ \\
\hline Iridocyclitis & $*$ & $*$ & $*$ & $*$ & $4.5 \%$ & $52.94 \%$ & $2.56 \%$ & $7.46 \%$ \\
\hline Choroiditis & $*$ & $3 \%$ & $*$ & $0.57 \%$ & $*$ & 2.52 & $3.25 \%$ & $4.47 \%$ \\
\hline CMV Retinitis & $3 \%$ & $4.7 \%$ & $17 \%$ & $10.6 \%$ & $11 \%$ & $10.92 \%$ & $5.1 \%$ & $12.43 \%$ \\
\hline HIV Retinopathy & $25 \%$ & $6.4 \%$ & $15 \%$ & $10.65 \%$ & $12 \%$ & $9.24 \%$ & $19.6 \%$ & $15.42 \%$ \\
\hline Optic Atrophy & $3 \%$ & $5 \%$ & $7 \%$ & $3 \%$ & $3 \%$ & $0.84 \%$ & $*$ & $1.49 \%$ \\
\hline PORN & $*$ & $*$ & $*$ & $*$ & $*$ & $*$ & $*$ & $1.49 \%$ \\
\hline RD & $*$ & $*$ & $*$ & $*$ & $*$ & $*$ & $*$ & $1.99 \%$ \\
\hline Dry Eye & $*$ & $*$ & $*$ & $*$ & $*$ & $*$ & $*$ & $*$ \\
\hline Blepharitis & $*$ & $*$ & $*$ & $*$ & $*$ & $*$ & $2.56 \%$ & $7.46 \%$ \\
\hline Conjunctivitis & $*$ & $*$ & $*$ & $*$ & $*$ & $*$ & $1.7 \%$ & $5.47 \%$ \\
\hline Nerve Palsy & $*$ & $*$ & $*$ & $*$ & $*$ & $*$ & $*$ & $*$ \\
\hline Styes & $*$ & $*$ & $*$ & $*$ & $*$ & $*$ & $*$ \\
\hline
\end{tabular}




\section{CONCLUSION}

1. The prevalence of ocular manifestations in HIV patients is $20.93 \%$.

2. Males are being more commonly affected than females and commonly involving age group is between $20-40$ yrs. of age.

3. HIV microangiopathy was the most common ocular manifestation in HIV patients and it was the common posterior segment manifestation.

4. Anterior segment being the commonly involved segment in HIV patients and common anterior segment manifestation was dry eye.

5. CMV retinitis was the most common opportunistic infection in patients with HIV and it was associated with CD4 count $<50$ cells/microlitre.

6. Patients on HAART therapy showing less manifestations compared to pre-HAART patients.

HIV/ AIDS is a disease at once amazingly virulent and shockingly new. Only a generation ago, it lay undetected. Yet in the past two decades by the rocking of the Joint UN Programme on HIV/ AIDS (UNAIDS), about 65 million people have contracted the illness and perhaps 25 million of them have already died. The affliction is almost invariably lethal. Scientists do not consider a cure to be even on the horizon. For now, it looks as if AIDS could end up as the coming century's top infectious killer.

At present, the HIV/ AIDS pandemic, though global, is overwhelmingly concentrated in Sub-Saharan Africa. Although, this situation has exacted a terrible human cost, the rest of the world has been largely unaffected by Africa's tragedy. Things will be very different, however, in the next major area of HIV infection. Eurasia (which for the purposes of this essay is considered to be the territory encompassing the continent of Asia plus Russia) will likely be home to largest number of HIV victims in the decades ahead. Driven by the spread of the disease in the region's three largest countries- China, India and Russia- the coming Eurasian pandemic threatens to derail the economic prospects of billions and alter the global military balance. And although the devastating costs of HIV/ AIDS are clear, it is unclear that much will be done to head off the looming catastrophe.

\section{REFERENCES}

[1] Sleasman JW, Goodenow MM. 13. HIV-1 infection. J Allergy Clin Immunol 2003;111(2 Suppl):S582-92.

[2] Centers for Disease Control (CDC). Revision of the CDC surveillance case definition for the acquired immunodeficiency syndrome. Council of State and Territorial Epidemiologists: AIDS Program, Center for Infectious Diseases. Morb Mortal Wkly Rep 1987;36(1):1S-15S.
[3] Fauci AS, Macher AM, Longo DL, et al. NIH conference. Acquired immunodeficiency syndrome: epidemiologic, clinical, immunologic and theraupetic considerations. Ann Intern Med 1984;100(1):92-106.

[4] Schuman JS, Orellana J, Friedman AH, et al. Acquired immunodeficiency syndrome. Surv Ophthalmol 1987;31:384-410.

[5] Holland GN, Pepose JS, Pettit TH, et al. Acquired immune deficiency syndrome. Ocular manifestations. Ophthalmology 1983;90(8):859-73.

[6] Freeman WR, Lerner CW, Mines JA, et al. A prospective study of the ophthalmologic findings in the acquired immune deficiency syndrome. Am J Ophthalmol 1984;97(2):133-42.

[7] Jabs DA, Green WR, Fox R, et al. Ocular manifestations of acquired immune deficiency syndrome. Ophthalmology 1989;96(7):1092-9.

[8] Pepose JS, Holland GN, Nestor MS, et al. Acquired immune deficiency syndrome. Pathogenic mechanisms of ocular disease. Ophthalmology 1985;92(4):472-84.

[9] Khadem M, Kalish SB, Goldsmith J, et al. Ophthalmologic findings in acquired immune deficiency syndrome (AIDS). Arch Ophthalmol 1984;102(2):201-6.

[10] WHO/UNAIDS/UNICEF “Global HIV/AIDS response: Epidemic update and health sector progress towards universal access" 2011.

[11] Sarraf D, Ernest JT. AIDS and the eyes. The Lancet 1996;348(9026):525-8.

[12] Holland GN, Gottlieb MS, Yee RD, et al. Ocular disorders associated with a new severe acquired cellular immunodeficiency syndrome. Am J Ophthalmol 1982;93(4):393-402.

[13] Cunningham ET, Margolis TP. Ocular manifestations of HIV infection. N Engl J Med 1998;339(4):236-44.

[14] Ather, Ahtesham M, Krishna SR. Incidence of Ocular involvement in HIV positive clients, Attending Integrated Counseling and Testing Centre, AIOC 2009.

[15] Lamichhane G, Shah DN, Sharma S, et al. Ocular manifestations in HIV/AIDS cases in Nepal. Nepal J Opthalmol 2010;2(1):45-50.

[16] Kestelyn PG, Cunningham ET. HIV/AIDS and blindness. Bull World Health Organ 2001;79(3):208-13.

[17] Jabs DA. AIDS and Ophthalmology in 2004. Archives of Ophthalmology 2004;122(7):1040-2.

[18] UNAIDS. Joint United Nations Programme on HIV/AIDS (UNAIDS). 2006 Report on the Global AIDS Epidemic, Geneva: 2006.

[19] Eong KGA, Beatty S, Charles SJ. Cytomegalovirus retinitis in patients with Acquired Immune Deficiency Syndrome. Postgraduate Medical Journal 1999;75(888):585-90. 